\title{
Stabilising an underground void: monolithic construction using self-consolidating concrete
}

\author{
A Pakula Golder Associates Ltd., Canada \\ R Preston Golder Associates Ltd., Canada \\ D Kennard Golder Associates Ltd., Canada \\ C MacInnis Crown-Indigenous Relations and Northern Affairs Canada, Canada
}

\begin{abstract}
In 2007, during a planned water level raise at the Giant Mine, which had recently been placed into care and maintenance, a large movement of fill occurred in a series of connected vertically stacked cut-and-fill stopes. The movement mobilised over 170,000 metric tonnes of previously placed unconsolidated rock and sand fill and left a 70,000 $\mathrm{m}^{3}$ void separated from arsenic trioxide storage vaults, by a thin sill pillar. Review of historical mine plans and investigations onsite suggested that timber sill mats and bulkheads which had likely destabilised when the area became variably saturated during flooding, created a connection between remnant voids in the upper and lower mining horizons resulting in the void. Furthermore, it was determined that if the water level was changed again, with either a rise or drawdown that the rock and fill within the stope below the void could once again be mobilised, further reducing the stability of the void. The mine is to be remediated and closed and a permanent solution to stabilising this void, which is approximately 85 to $125 \mathrm{~m}$ below ground surface, was required. Given the lack of future underground access and a desire by the project proponent to reduce long-term monitoring and care requirements, a unique solution was required.

While stabilising mine voids during active production mining or during mine closure activities, practitioners would typically utilise a cemented mine waste product such as cemented rockfill (CRF), cemented paste backfill (CPB) or cemented sand fill. Because of the potential for the previously placed sand and rockfill in the void to move deeper into the mine void and possibly destabilise the workings, a manufactured sill pillar that would stay in place should the material below it move was required. In this case, it was determined that the void span was sufficiently large that these types of materials would not be self-supporting should such a movement occur. Therefore, a self-consolidating concrete (SCC), also known as self-levelling concrete was used to manufacture a 16,600 $\mathrm{m}^{3}(70 \times 24 \times 10 \mathrm{~m})$ monolithic concrete sill pillar to be installed.
\end{abstract}

Keywords: mine closure, manufactured sill pillar, self-consolidating concrete, self-levelling concrete, arsenic, arsenic trioxide, Giant Mine, Giant Mine Remediation Project, mine backfill, remediation, stope stabilisation

\section{Introduction}

The Giant Mine is located approximately $5 \mathrm{~km}$ north of Yellowknife, NT Canada on Great Slave Lake (Figure 1). The mine was operated by multiple companies from the late 1940's until 1999, when bankruptcies resulted in the property becoming 'orphaned' and by default, the owner became the Government of Canada. The mine continued to operate under 3rd party agreements until operations ceased in July 2004 and the mine was placed into care and maintenance (Silke 2009). The Giant Mine Remediation Project (GMRP) endeavours to close the mine and during ongoing assessment of the site, some immediate ground stability issues were identified including a large void situated below underground arsenic trioxide-containing vaults.

While in care and maintenance, access to key areas of the underground have been preserved for the purpose of servicing dewatering pumps to maintain the water level within the mine at approximately $245 \mathrm{~m}$ below ground surface (mbgs), and for planned future mine void stabilisation work. 


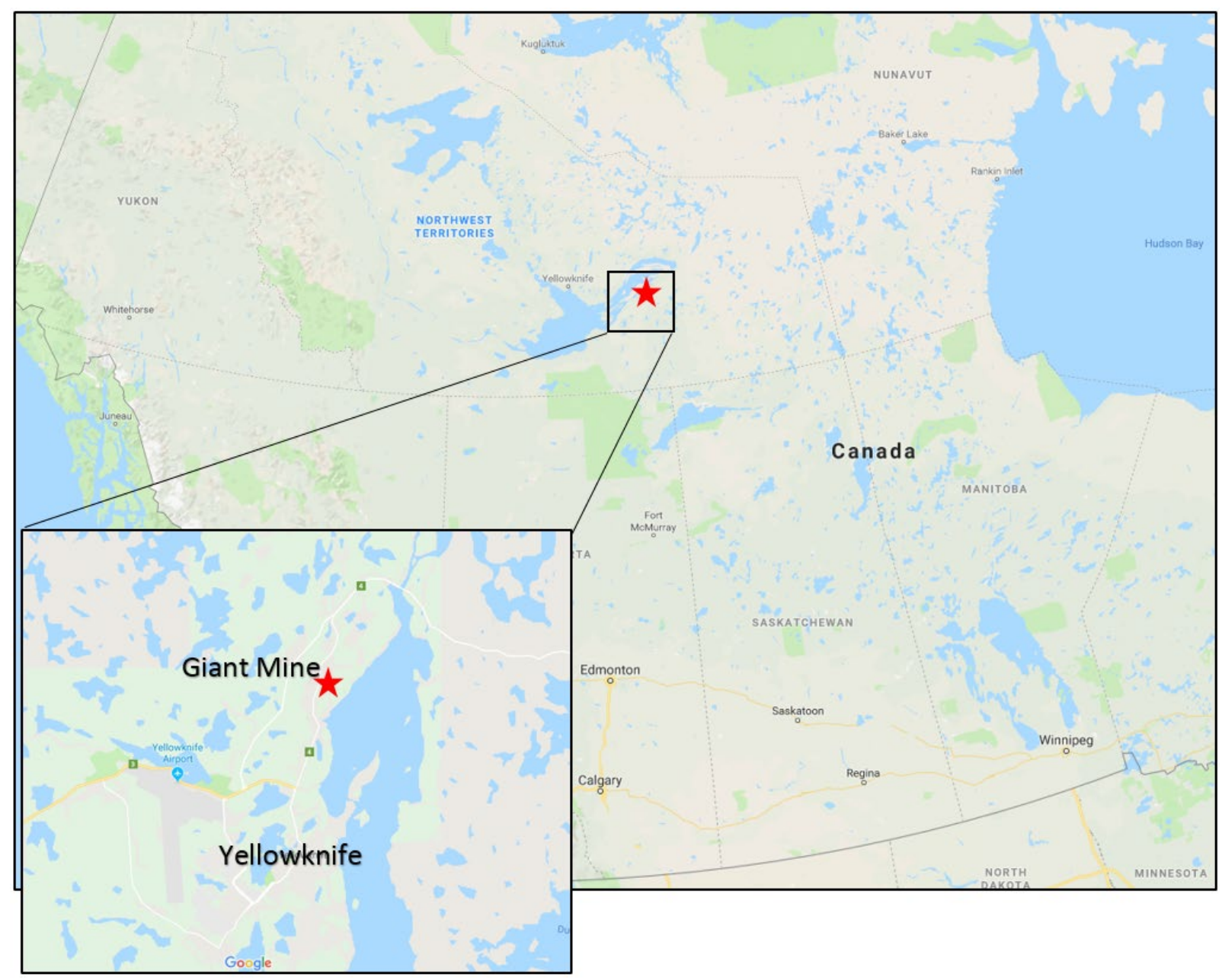

Figure 1 Location of Giant Mine (Google n.d.)

\section{Background information}

The background of the GMRP and plans to close the mine are well described in the recently published closure and reclamation plan (Crown-Indigenous Relations and Northern Affairs Canada \& Government of the Northwest Territories [CIRNAC \& GNWT] 2019).

During operation, the mine extracted approximately 7.12 million ounces of gold from a typically steeply dipping narrow shear zone in a greenstone host rock. The process used by the mine to extract the gold from the host rock required that the ore be heated (roasted) to high temperatures $\left(500^{\circ} \mathrm{C}\right.$ ) after an initial floatation process and arsenic trioxide dust was produced as a byproduct during the roasting process. The arsenic dust was captured and pumped pneumatically to underground vaults developed in previously mined-out ore bodies, called stopes, and purpose-built excavated cavities, called chambers, that were developed specifically for the storage of the arsenic trioxide. Approximately 237,000 tonnes of arsenic trioxide were stored in these underground stopes and chambers.

The locations of the stopes and chambers which contained the arsenic trioxide were often close to other production mining areas. As mining progressed, the excavation of other ore bodies encroached on the stopes and chambers which contained the arsenic trioxide, causing concern for the stability of the unsupported remaining rock (rib and/or sill pillars) separating the advanced mining areas with the arsenic trioxide stopes and chambers. Such voids were backfilled with unconsolidated rock and sand fill to stabilise them.

Within an area of the mine which contained one arsenic stope (C212) and two arsenic chambers (C9 and C10), multiple non-arsenic stopes (referred to as the C509 stope complex) had been excavated within close proximity to each other (Figure 2). 


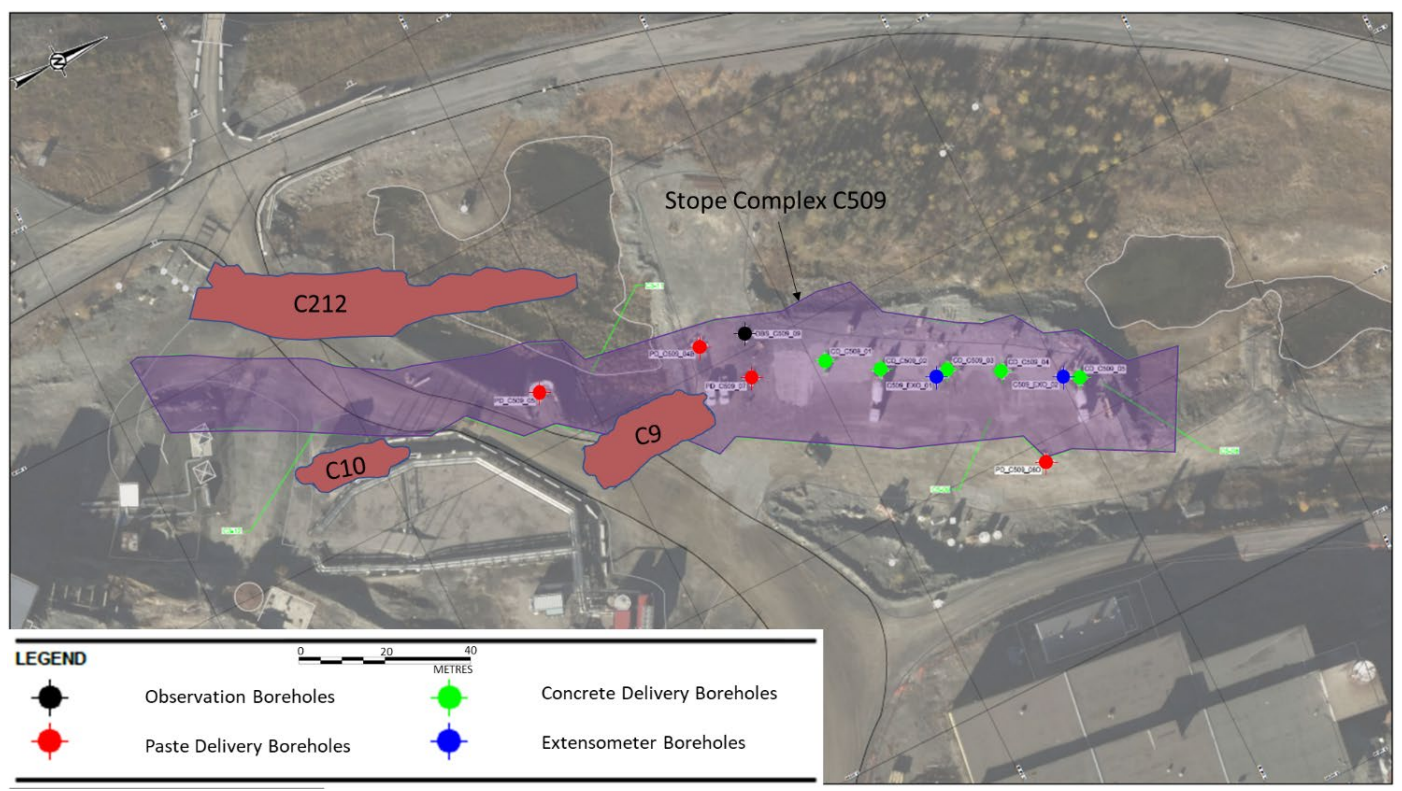

Figure 2 Location of arsenic stopes and chambers (red) in relation to non-arsenic stope complex C509 (purple)

The C509 stope complex consisted of several interconnected, partially-filled near vertical cut-and-fill stopes. The highest point of the $\mathrm{C} 509$ was approximately $85 \mathrm{~m}$ below surface (mbgs) extending to $250 \mathrm{mbgs}$ where a thin sill partial sill pillar and sill mats separated it from even deeper mining. The stope was up to $220 \mathrm{~m}$ long on strike, between 5 and $25 \mathrm{~m}$ wide, and $170 \mathrm{~m}$ high. It was separated from the $\mathrm{C} 212$ stope by a $10 \mathrm{~m}$ thick boundary pillar. The C10 and C9 arsenic chambers are located above and slightly offset from the C509 complex by an approximate $20 \mathrm{~m}$ thick sill pillars. The geometry of the original stope is shown in longitudinal geological section as the various shaded areas (Figure 3 ) which include partial rock and sand fill and void.

As noted above, in 2007 during a planned mine water elevation raise, a sill matt, located below the C509 stope is believed to have failed, causing the backfill to exit the stope. The remnant void created at the top of the stope had an approximate $70,000 \mathrm{~m}^{3}$ volume, was measured to be $70 \mathrm{~m}$ long $\times 22 \mathrm{~m}$ wide $\times 40 \mathrm{~m}$ high as shown (Figure 3).

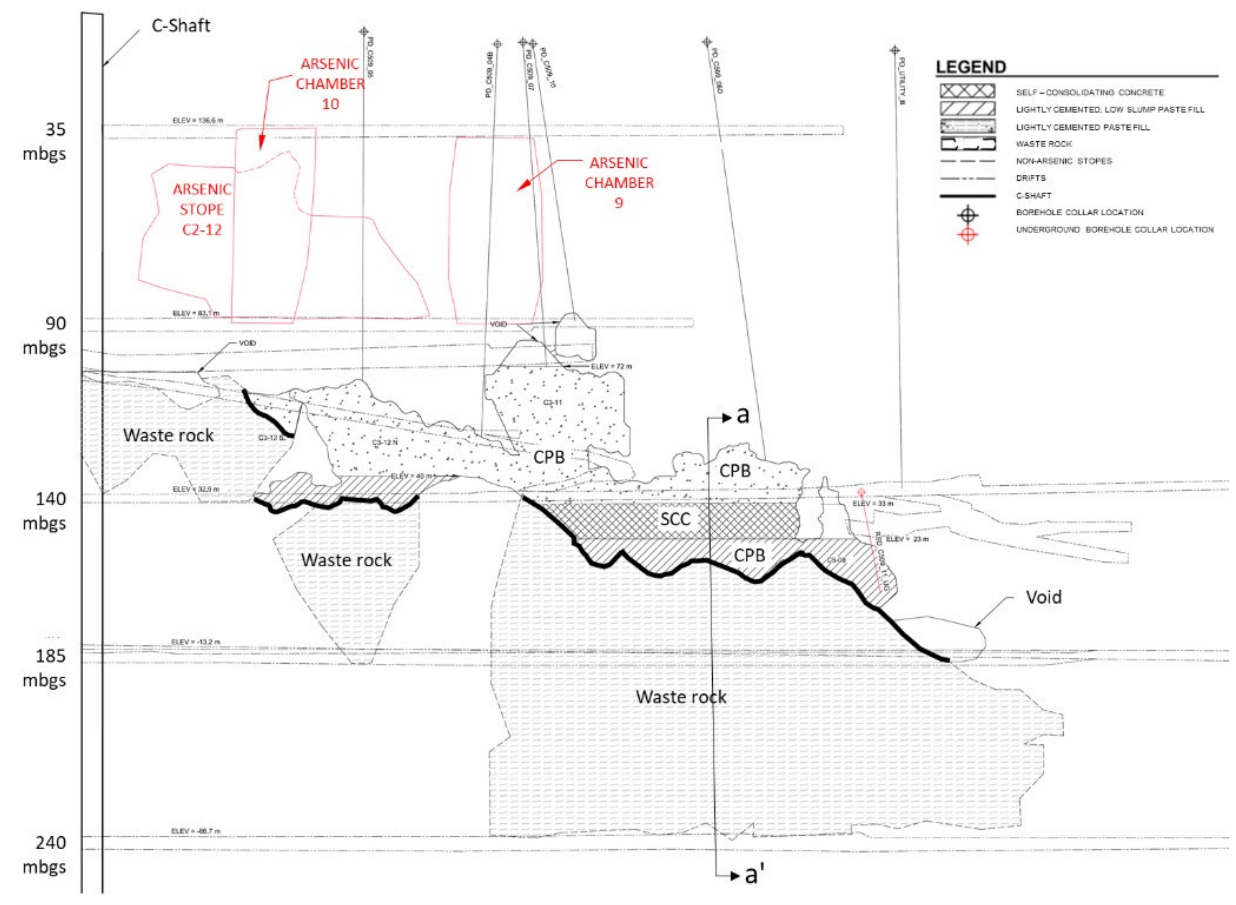

Figure 3 Long section of the C509 stope complex showing levels and adjacent arsenic stopes 
The void shape was generally wider at the top portion, gradually narrowing to semi-vertical hanging wall and footwall (Figure 4). Current Cavity Monitoring Survey results show that the C509 stope is wider than shown in historic mine plans, suggesting that the stope walls have previously failed, or that undocumented mining occurred (Figure 4).

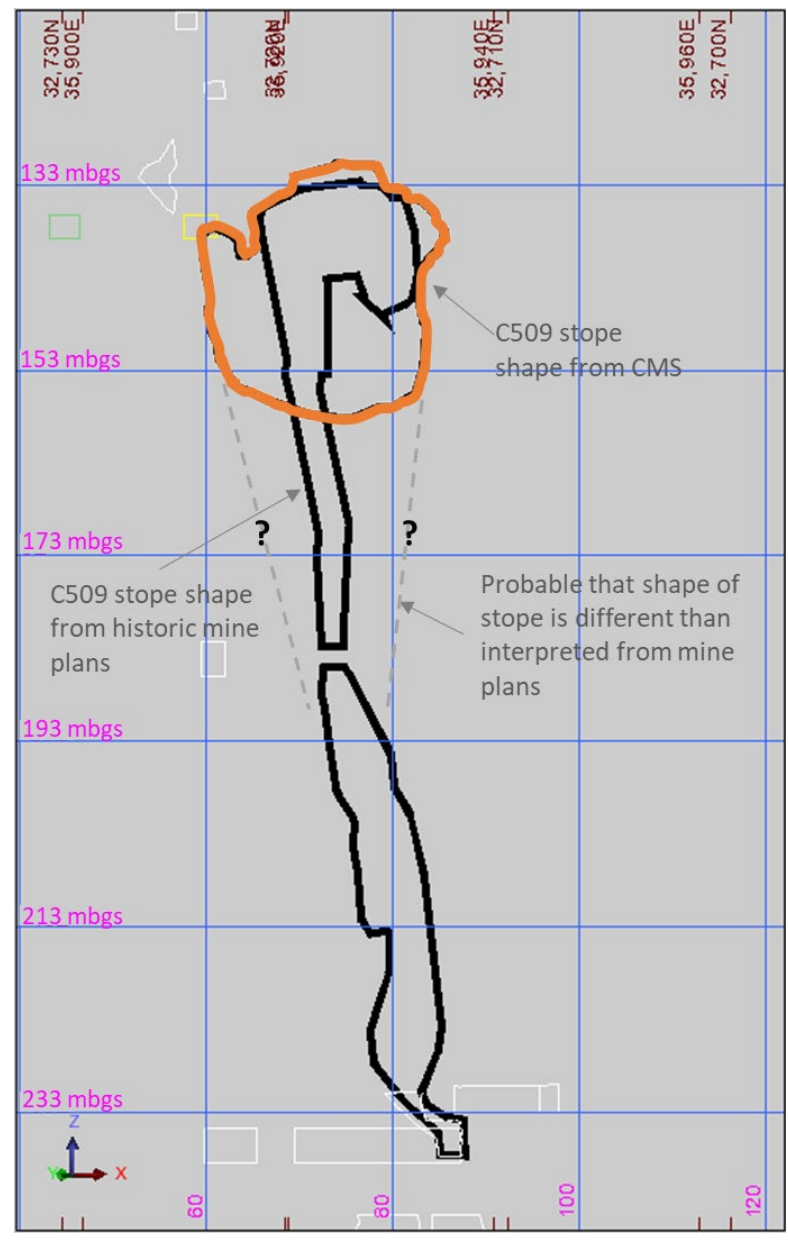

Figure 4 Vertical cross-section (a-a') showing typical shape of the C509 void

\section{Design approach}

During the 100-year design life of the GMRP, planned or possible future water level changes could result in destabilisation of the existing sand and rockfill in the stope below the void which would decrease its stability. Given the proximity of the overlying arsenic stopes and chambers, this was deemed an unacceptable risk to the project, as development of a connection between arsenic storage vaults and deeper mine workings and the current mine water level in the partially flooded mine could have a major impact on the surrounding communities if arsenic trioxide were to enter the mine pool and potentially downstream water sources, including Yellowknife Bay. Therefore, the design for the backfilling of the C509 stope complex required that whatever material that was placed in the void to stabilise it had to remain stable if the pre-existing sand and rockfill below continued to migrate further into the underground mine.

\subsection{Investigation and compilation of the history of mining the C509 stope complex}

A desktop review of the historical mining records for the C509 stope complex was completed to determine the connectivity of the $\mathrm{C} 509$ stope complex with mine voids at elevations below the mine water level. During this review, it was determined that significant gaps in understanding the C509 complex still existed. Therefore, following the desktop review, an extensive investigation of the underground was completed in 2016. During this investigation, borehole camera surveys were completed through existing historical 
exploration boreholes and underground unmanned aerial vehicle surveys and underground inspections were conducted from open-breakthrough locations of the development mining (Preston \& Roy 2017). Finally, 10 boreholes were drilled from the 250 and 425 mining levels (approximately 90 and $140 \mathrm{mbgs}$ ) into underground areas where gaps remained after completion of the other investigation methods.

Results supported the interpretation that during mining activities, the C509 stope had been excavated to a larger cross-sectional dimension than was represented in the historical mine plans. This conclusion confirmed the necessity of a structural member (manufactured sill pillar or plug) within the void space in order to maintain support of the crown pillar in the event of additional fill movement during future planned water elevation changes.

\subsection{Design criteria}

The stability of the backfill within the C509 stope required that the manufactured self-supporting sill pillar span the approximately $20 \mathrm{~m}$ wide stope and to be self-supporting, in addition to supporting the load of overlying Cement Paste Backfill (CPB) designed to stabilise the stope crown. If the underlying, unconsolidated sand and rockfill within the stope was to migrate deeper into the mine, then the support structure would remain in place during the time it would take to procure a contractor to again stabilise the backfill materials.

From this assessment, it was determined that the criteria for the backfill material required that:

- The placed backfill have a design life of at least 100 years to satisfy the design life.

- The material placed within the stope be self-supporting across the width and length of the stope, approximately $20 \times 70 \mathrm{~m}$ at the widest point.

Due to the size and nature of the void, the stope was designated as a non-entry stope and anything constructed within the stope had to be placed using remote construction, either through remotely controlled equipment or by installation of a flowable backfill material.

Based on these criteria, the design team concluded that durability of the material placed within the stope was paramount. The structural design of the sill pillar required that the member be constructed:

- With concrete having an unconfined compressive strength of $12 \mathrm{Mpa}$.

- As a monolithic construction, such that there were no weak horizontal planes, or cold joints.

- To reduce the maximum and differential temperature of the concrete to the extent possible to reduce the probability of getting any shrinkage cracks.

Given the remote-placement requirement, self-consolidating concrete (SCC) was chosen for its ability to flow and cover the $20 \mathrm{~m}$ span of the stope, while limiting the number of required delivery holes.

Numerical analysis of the proposed sill pillar concluded that it would need to be $10 \mathrm{~m}$ thick (additional detail in Section 3.3) in order to maintain a stable arch in the event of fill migration below. A section of the C509 stope void, from 141 to $151 \mathrm{mbgs}$, was identified as the location in which to construct the structural member.

\subsection{Design}

The manufactured sill pillar was designed to be installed between 141 and $151 \mathrm{mbgs}$ where the hanging wall and footwall of the stope was either near vertical, or tapered with a slight wedge shape. This elevation was also chosen as it achieved the full $10 \mathrm{~m}$ thickness without being interrupted by undulations in the stope back (Figure 3) and was the only location were the sill pillar could be constructed where there was rock wall to rock wall contact on three sides over the full length of the pillar. Due to the shape of the stope and the existing backfill that had been placed previously, the south end of the manufactured sill pillar was to be founded on unconsolidated backfill material.

A two-dimensional numerical stress model was used to simulate the stability of 12 cross-sections along the strike length of the designed sill pillar to interpret the performance of the pillar for rotational, sliding and 
crushing failures. Various cases for surcharge loads acting on the manufactured sill pillar were run to confirm that it could carry the maximum design loads from perched water and other backfill materials placed on top of the sill pillar. Results of the compressive strength Factor of Safety (FoS) ranged typically from 3 to 7 . The FoS for tensile strength along the 12 sections ranged from greater than 1 to less than unity in some cases. However, results less than one were expected for an unreinforced structure, and further analysis was completed to determine the stresses produced from propagation of cracking into the structure. It was found that at a depth of $3 \mathrm{~m}$ into the sill, the estimated tensile stress still exceeded the allowable tensile stress (Figure 5). However, when the crack propagated to a depth of $6 \mathrm{~m}$, the tensile stresses generated were within the acceptable limits. At a depth of $6 \mathrm{~m}$ into the sill pillar, there was still sufficient thickness remaining above the fracture for a compression arch to perform within the allowable stresses.

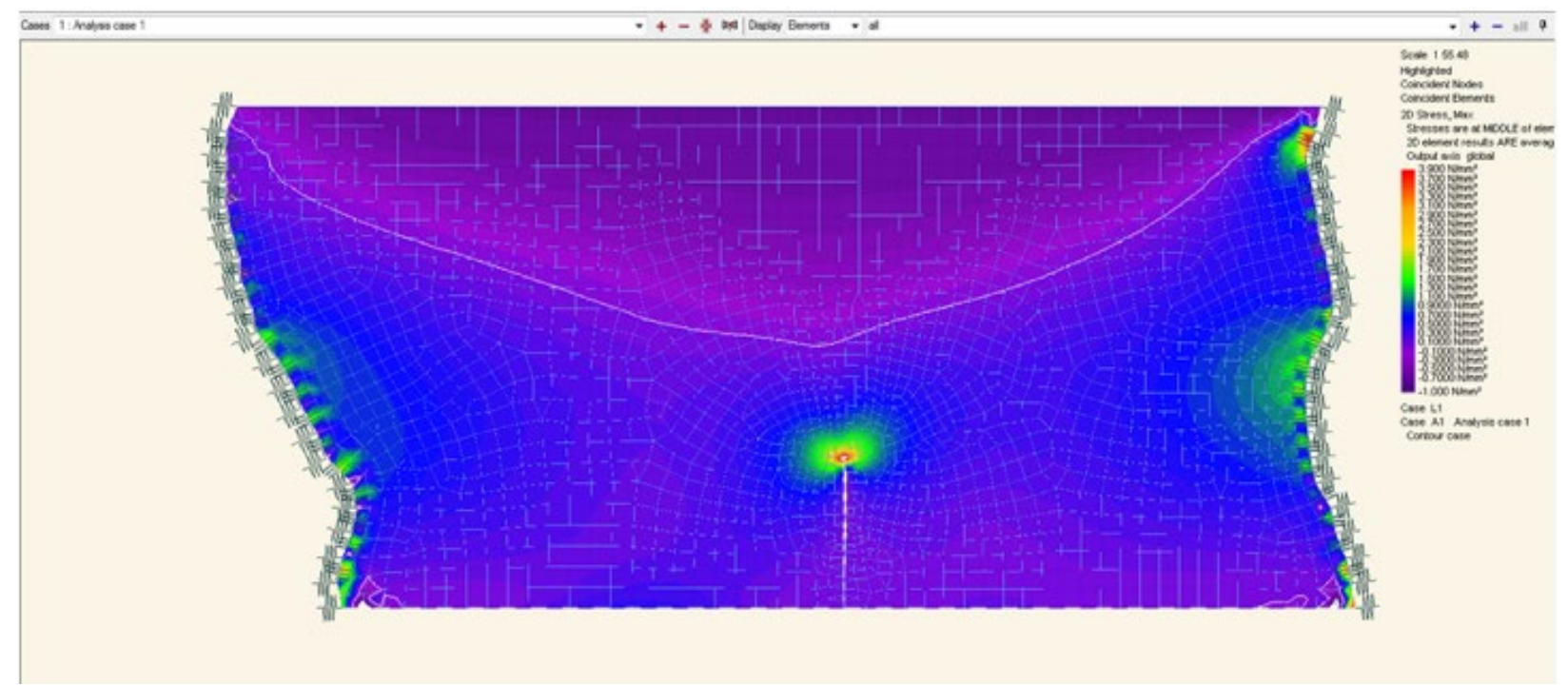

(a)

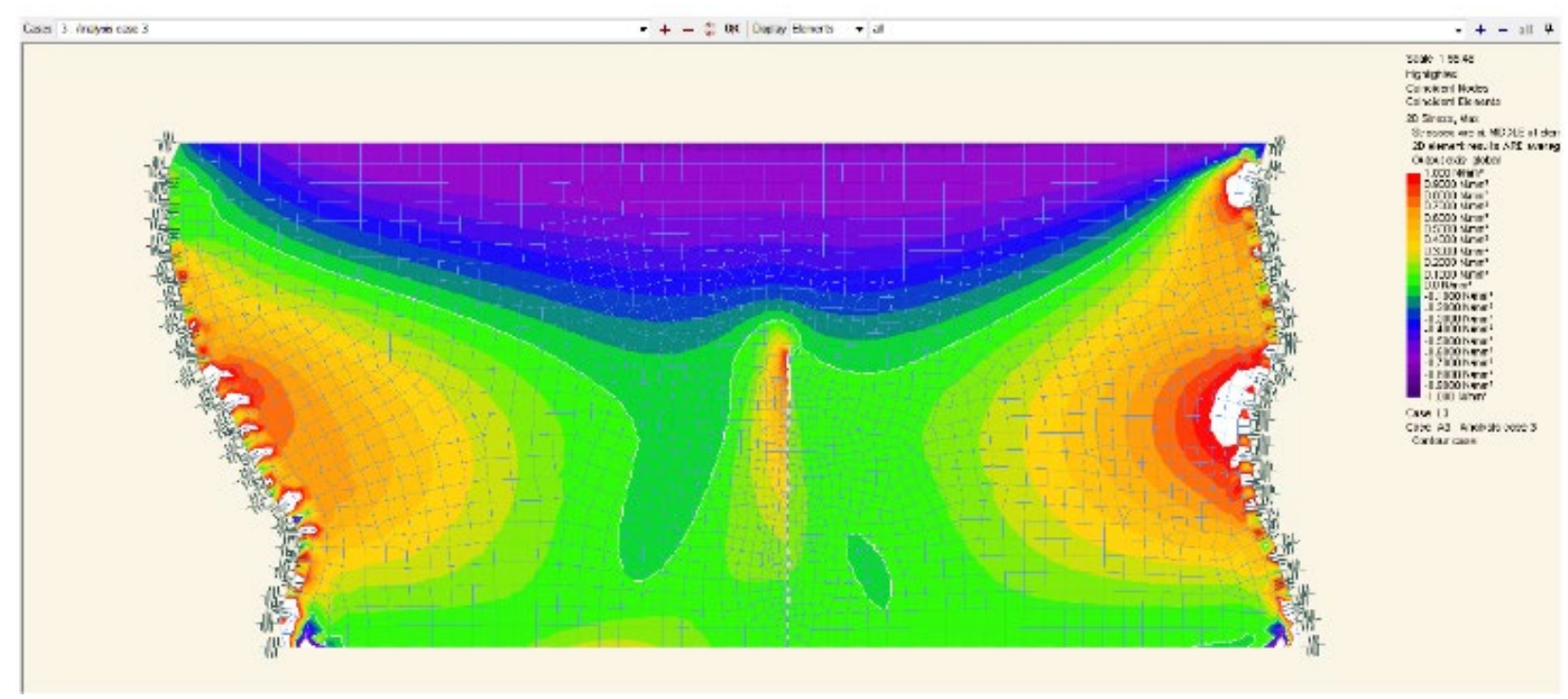

(b)

Figure 5 Example 2D numerical stress model showing (a) $3 \mathrm{~m}$ crack and (b) $6 \mathrm{~m}$ crack. It was found that there was sufficient depth remaining above the $6 \mathrm{~m}$ crack for a compression arch to perform within the allowable stresses. Hot-cold colour scheme of tensile stress with purple and blue indicating compressive stress (Rocscience n.d.) 


\section{$4 \quad$ Planning}

Once the design had been developed, the constructability of the manufactured SCC sill pillar was considered. This process included:

- Sourcing and testing locally available aggregates.

- Sourcing binder.

- Completing SCC trial batching.

- Developing technical specifications.

\subsection{Aggregates}

Aggregate materials were sourced from onsite aggregate stockpiles which were left over during quarrying operations and from local aggregate suppliers. The material selected for sampling consisted of unprocessed, $50 \mathrm{~mm}$ minus crushed aggregates, which had an angular and platy shape (long and thin). Due to the unfavourable shape of the aggregates for a flowable concrete, additional screening and crushing of the material was completed to achieve the desired gradation and aggregate shape.

Naturally-rounded fine grained aggregates are typically specified for SCC; however, due to their limited supply in Yellowknife, the fines particulate had to come from alternative sources. For the trial batching, these fines were sourced from sand suppliers in Yellowknife and consisted of a mixture of natural sand and fines remaining from aggregate crushing activities, i.e. crusher dust.

\subsection{Binder}

As naturally-rounded fine and course aggregates were limited for this project, and heat generation during the pouring of the SCC was to be controlled, it was recommended that a portion of the General Use Portland Cement be replaced with a suitable supplemental cementitious material (SCM).

Supply of the quantity of binder needed was deemed a risk to the project to ensure that the construction could continue without interruption. Due to the distance of travel for the binder (trucked approximately $1,500 \mathrm{~km}$ from Edmonton, $\mathrm{AB}$ ) and that the supply had to be continuous, the preferred SCM was Type F Fly Ash, which is a significant byproduct of power generation in Alberta. While Fly Ash was preferred, due to the naturally-rounded particulate shape, other SCM's could be used. The SCM replacement of General Use, or Ordinary Portland Cement of between $70 \%$ and $90 \%$ was preferred for this project.

\subsection{Testing self-consolidating concrete mix designs}

Once the constituents of the SCC had been selected, a test program was developed to determine the appropriate mix design which met the project requirements.

The project requirements were:

- SCC set time of between $18-24 \mathrm{hrs}$.

- Achieve a maximum concrete temperature of $70^{\circ} \mathrm{C}$ and a temperature gradient between the interior and exterior portions of the concrete not to exceed $20^{\circ} \mathrm{C}$.

- Achieve bleed of less than $1 \%$ by volume.

- Non-segregating at the point of delivery into the stope.

- Achieve a slump flow of $625 \pm 25 \mathrm{~mm}$ after all constituents had been added to the mix.

- Achieve a design strength of $12 \mathrm{MPa}$ at 28 days.

A total of 16 trial batches were developed to test the various combinations of course and fine aggregate and various dosages of binder and chemical admixtures. 
To achieve the desired properties, a total cementitious material content of $400 \mathrm{~kg} / \mathrm{m}^{3}$ and a water to cement ratio of 0.42 were used. While this produced a SCC with greater than $12 \mathrm{MPa}$ at 28 days, it was found that the additional ultrafine content was required to achieve the desired flow properties.

Assessing the total heat generation was completed using the semi-adiabatic calorimetry method. Samples were cured in a fridge to mimic the conditions of the underground stope. The maximum generated heat was modelled to be $37^{\circ} \mathrm{C}$ to $45^{\circ} \mathrm{C}$, while the differential temperatures were modelled to be $23^{\circ} \mathrm{C}$ to $32^{\circ} \mathrm{C}$. While the modelled maximum temperature was estimated to be within the design specifications, the differential temperature was estimated to be higher than specified for the project. Due to the complexity of managing the differential temperature by heating the underground rock or other means, the project proponent decided to move forward with the project despite the potential risk of high differential temperatures developing across the sill pillar increasing the potential for shrinkage cracking.

\section{Construction}

The importance of the long-term integrity of the sill pillar/plug construction was paramount to achieving the objectives of the project. A levelling pad of CPB was poured prior to SCC placement within the C509 stope to provide some consolidation and strengthening of the upper portions of the previously placed un-cemented rockfill. The intention was that the CPB would fill void space within the top layer of the rockfill, and then provide a small surcharge load to the fill before the SCC was placed on top.

The SCC sill pillar was poured from 20 September 2018 to 21 October 2018, over a period of 31 days. Five, approximately $100 \mathrm{~m}$ long, $203.2 \mathrm{~mm}$ (8 inch) diameter pipes were lowered into the stope on an average $15 \mathrm{~m}$ spacing for SCC delivery. The sequence of SCC delivery to each hole was generally sequential but was adjusted so that a fresh layer of SCC was maintained over the extents of the stope. The pipes were initially intended to be used as tremies; however, during operation it was found that the frictional losses along the length of the pipe were too great to allow for delivery with the pipe tip submerged in SCC. Instead, the pipes were kept above the SCC surface and SCC was free-poured into the pipes. As a result of allowing the SCC to free fall, bowl-like plunge pools formed at the tip of each pipe which helped to disperse the fall energy and provide re-mixing prior to the SCC flowing into the stope.

During placement, the production rates were maintained at between 12 and $34 \mathrm{~m}^{3} / \mathrm{hr}$ to ensure that there was a fresh surface of SCC maintained at all times. The required pouring rate was estimated based on the radial influence of each borehole and the set time of the SCC, which was initially estimated at 12-18 hours but was later updated to 18-23 hours based on field laboratory tests.

The SCC was produced at a batch plant that dry mixed the binder and aggregates prior to adding water and admixtures. The SCC was then mixed and transported to the delivery holes via mixer truck.

Approximately 9 days into production, the SCC delivery rate was slowed to mitigate against exhausting the cement binder supply. Measures were taken to ensure that a live leading edge was maintained to prevent the formation of a cold joint within the manufactured sill pillar. These included calculating the expected SCC rise for the volume delivered within a period equivalent to the initial set time and taking regular measurements of the SCC rise using staff gauges to verify that the level was coming up as expected. A separate binder source was also secured in order to provide a continuous supply of binder.

\section{Instrumentation}

Prior to backfilling operations, several infrared cameras were installed into the stope complex at breakthroughs with drifts and drawpoints. The video feed from the cameras was relayed to surface and monitored in real time. The camera feeds were used to read staff gauges placed within the stope, markers of pipes lowered into the stope from surface and monitor the flow of SCC.

Once the CPB was placed in the void up to the 151 mbgs elevation, two vibrating wire inline extensometers, with 10 nodes were installed from surface into the void (Figure 6). To ensure proper installation, the extensometers boreholes were drilled at a $90^{\circ}$ angle, with a drilling tolerance of $1 \%$, to ensure that the angle 
of the borehole at breakthrough into the void was as close to vertical as possible. Prior to extensometer installation, a PVC sleeve with reflective tape affixed to the PVC at $0.5 \mathrm{~m}$ intervals, was installed into the borehole from surface to within $1 \mathrm{~m}$ of the CPB surface. The 10 node extensometers (with thermistors) were then installed through the PVC to the CPB layer. The PVC sleeving was intended to reduce the lateral force on the extensometers and prevent damage due to the SCC flow from the tremie into the stope. One node with thermistor was installed so that it rested on the CPB layer to provide a temperature and settlement data of the bottom of the SCC layer (Figure 7).

Due to the weight and method of installation, some of the extensometers became extended during installation, prior to being engulfed in SCC (30.9 and $40.9 \mathrm{~m}$ elev in Exo 1, 22.2 and $40 \mathrm{~m}$ in Exo 2) and the extensometer became unreliable. However, the thermistor associated with that particular node continued to function normally.

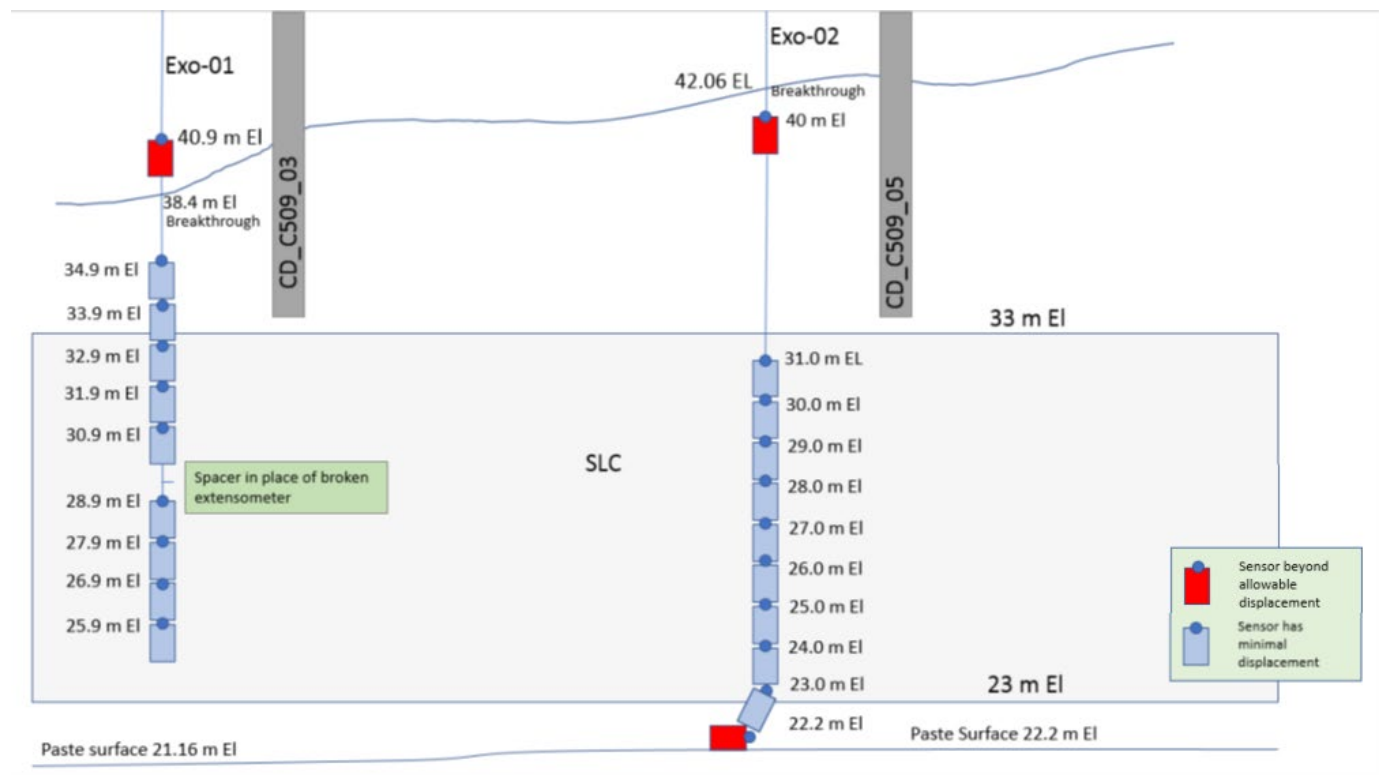

Figure 6 Vertical schematic long section of the extensometers installed in the C509 sill pillar during placement (not to scale)

During SCC pouring, the PVC sleeve was lifted using a hydraulic casing jack on surface to ensure that the PVC did not become lodged in the SCC (Figure 7). At times, the PVC temporarily caught on the extensometers, creating false displacement that quickly corrected itself upon completion of jacking.

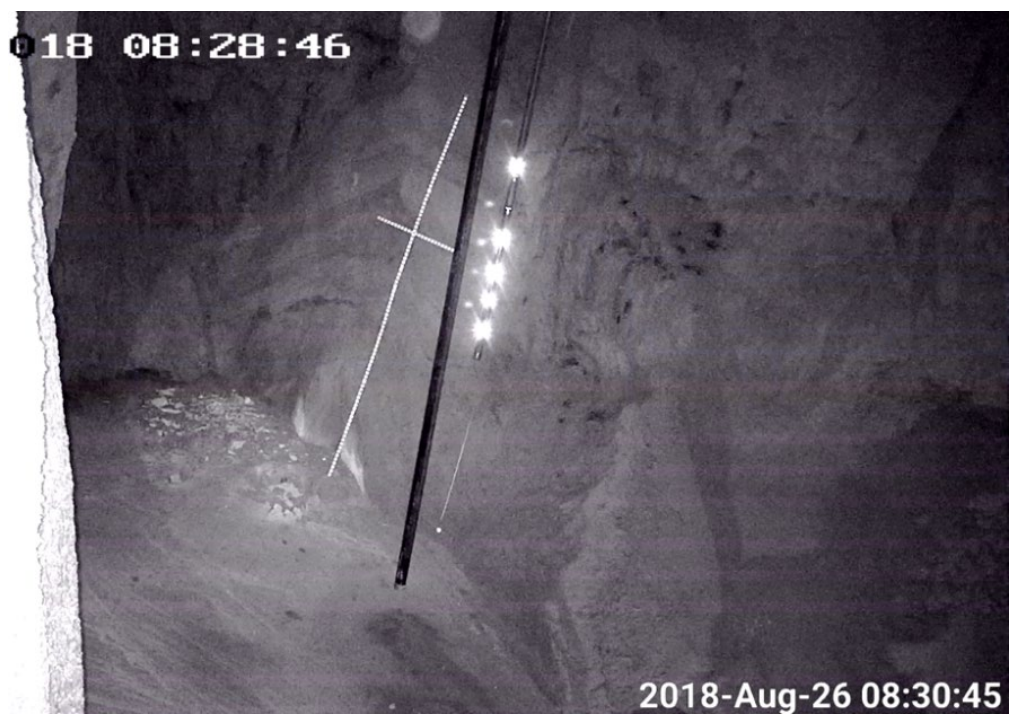

Figure 7 Reflective strips shown as bright white marks on the PVC in the infrared camera picture 
The extensometers were wired into data loggers and set to collect data every 1 minute during pouring operations (Figure 8). The data were downloaded daily and reviewed. Interpretation of the data is discussed in Section 6.

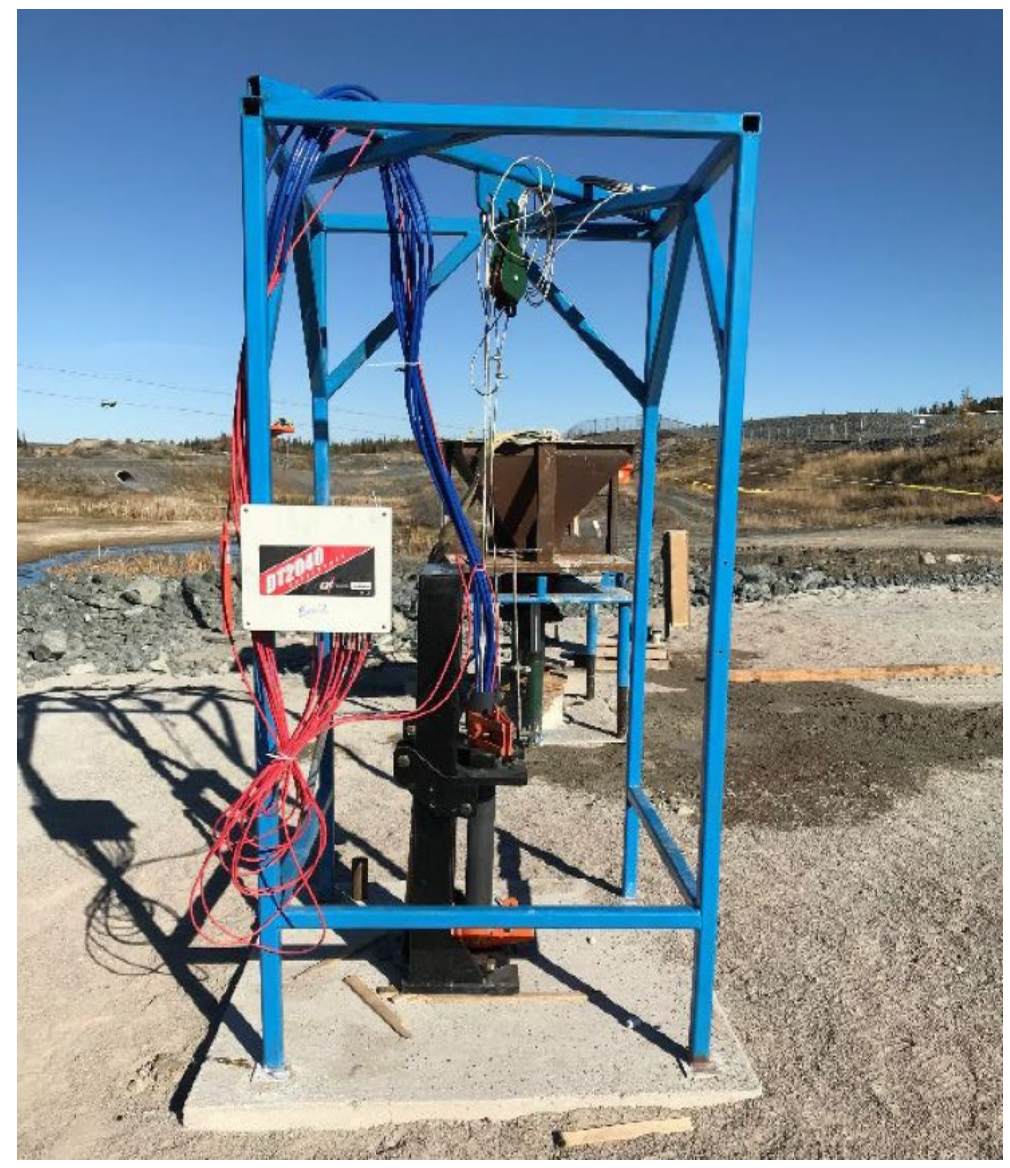

Figure 8 Extensometer support stand (blue) with data logger and casing jack (black)

\section{$7 \quad$ Performance}

During placement, the quality of the SCC was monitored via quality control and quality assurance sampling at the delivery hole and subsequent laboratory testing. Testing consisted of: slump flow (ASTM International 2014b), visual stability index (ASTM International 2014b), set time (ASTM International 2016), bleed (ASTM International 1998), temperature, aggregate particle size distribution (ASTM International 2014a) and, Unconfined Compressive Strength (ASTM International 2018). Testing confirmed that the majority (>90\%) of SCC placed met the required performance specifications.

In situ performance was monitored using data from the extensometers and their thermistors. The extensometer data showed minimal displacement over the course of the pour, with generally 0.6 to $1.0 \mathrm{~mm}$ of compression observed after engulfment with SCC. The sensor located at $40.9 \mathrm{~m}$ elevation (top of the CPB) exhibited $0.6 \mathrm{~mm}$ of extension after engulfment suggesting the CPB shrunk during curing or the sill pillar dropped by $0.6 \mathrm{~mm}$ (Figure 9). This sensor will be used long-term to monitor overall sill pillar displacement, as the top of the sensor is secured into bedrock. This assumes that the sill pillar moves as one complete unit and doesn't delaminate.

Thermistor data showed that the concrete reached a peak temperature of approximately $40^{\circ} \mathrm{C}$ with a range of $31^{\circ} \mathrm{C}$ to $40^{\circ} \mathrm{C}$ (Figure 9). The thermistor on the bottom of the SCC, up against the paste registered a max temp of $29^{\circ} \mathrm{C}$ which suggests a max differential temperature of $10^{\circ} \mathrm{C}$. This matches relatively well with initial modelling that predicted a peak core temperature of $37-45^{\circ} \mathrm{C}$. However, the actual maximum differential temperature of $10^{\circ} \mathrm{C}$ was significantly less than the modelled differential temperature of $23^{\circ} \mathrm{C}$ to $32^{\circ} \mathrm{C}$. The 
temperature remained relatively consistent up to the last reading in December 2018, possibly because CPB was placed on top and insulated the SCC.

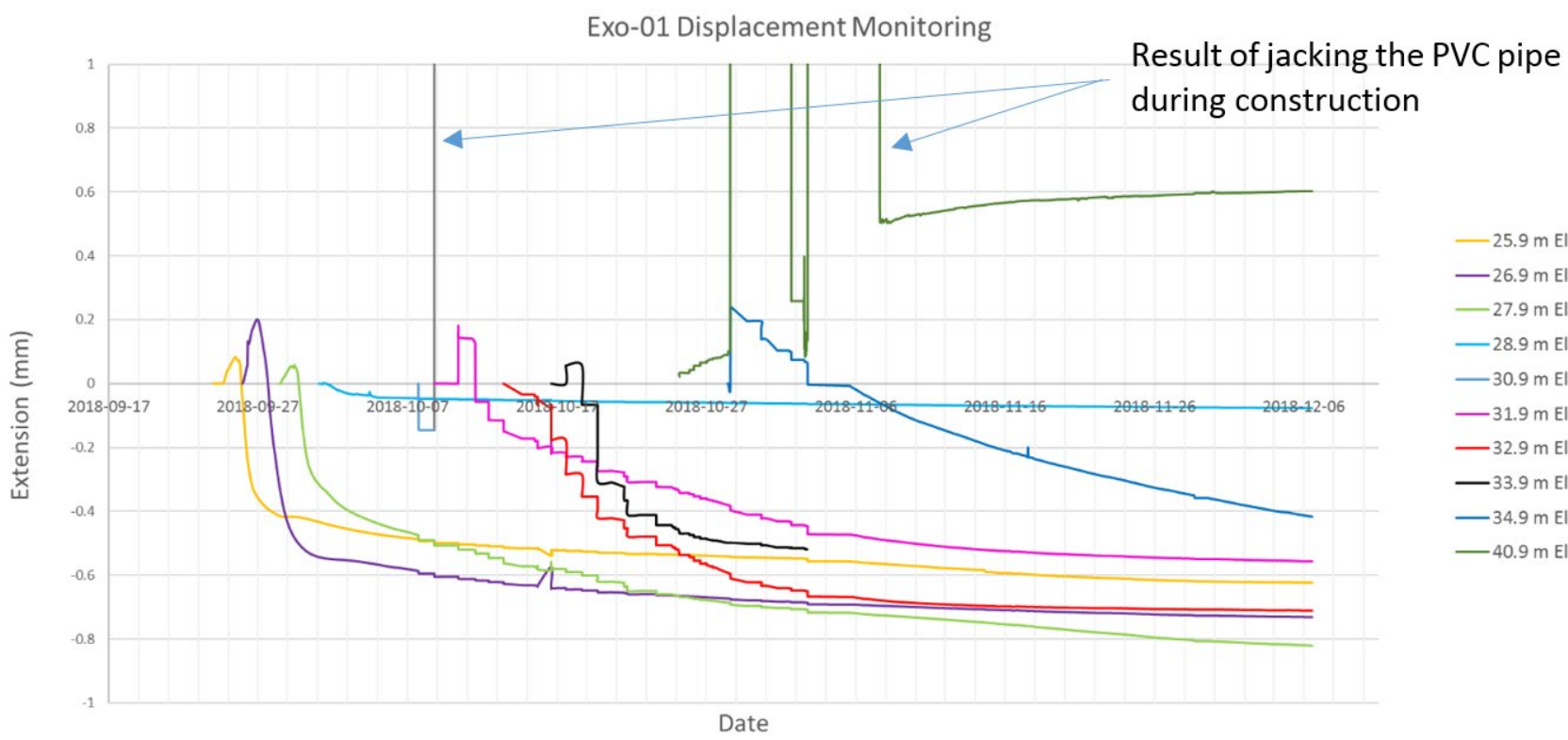

(a)

Exo-02 Temperature Monitoring

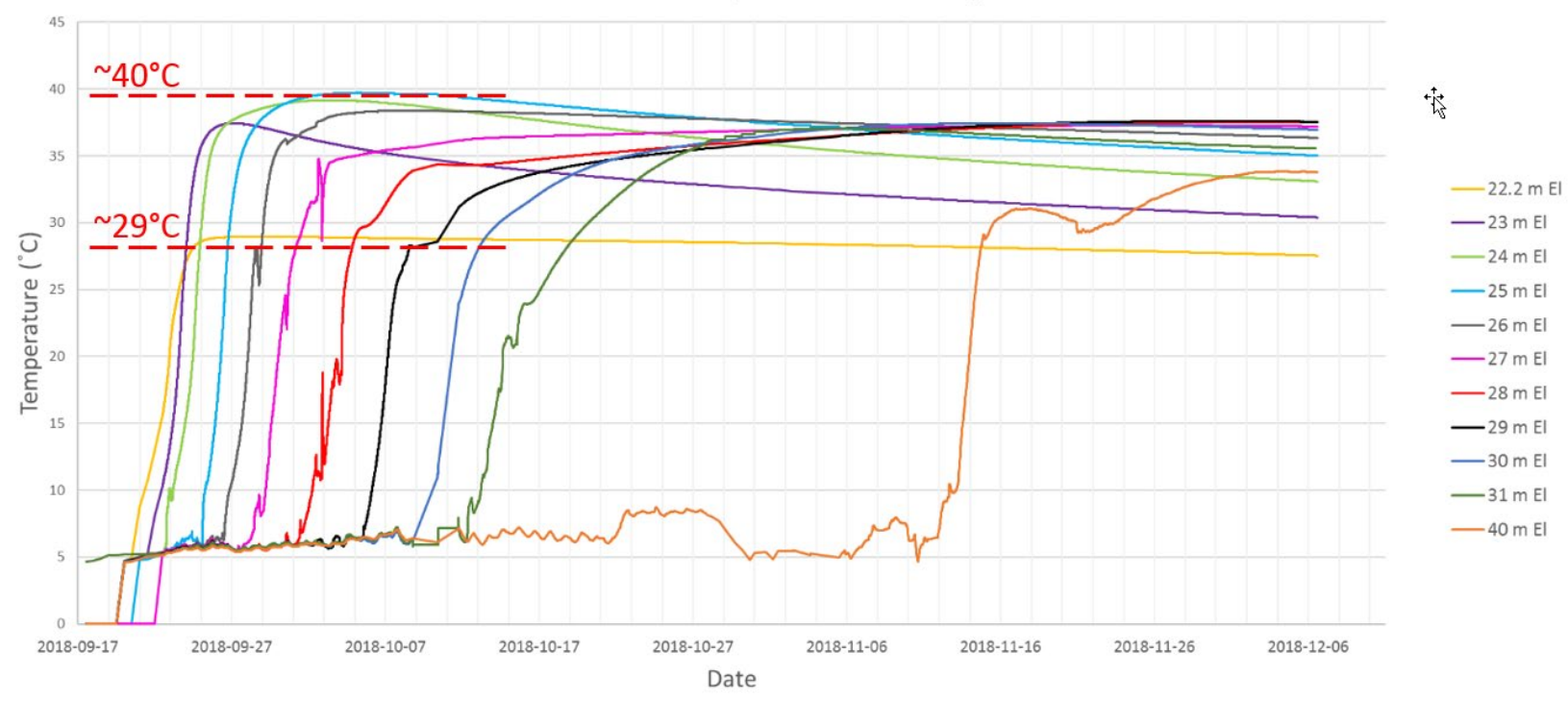

Figure 9 (a) Extensometer and (b) temperature data collected during SCC pour

A monitoring program is in development to confirm the long-term performance of the pillar and will include a drilling investigation to collect in situ samples to verify the in situ performance of the SCC.

\section{Conclusion}

Stabilisation of the C509 stope at the GMRP was a critical risk that needed to be addressed and was a key early step in dealing with geotechnical hazards on the site which is to be closed (CIRNAC \& GNWT 2019). Due to known and unknown conditions, typical stabilisation approaches, such as cemented paste backfill, or cemented sandfill were found to not be suitable for this particular application. Therefore, an unconventional approach was undertaken. 
The detailed site investigation and stope characterisation for optimal placement of the SCC sill pillar was instrumental in developing a sill pillar design that could be self-supporting if future fill movements occur within the stope. By completing detailed scanning of the void, areas where the stope tapered towards the bottom were identified and prioritised for construction of the sill pillar.

As a result of the detailed design and planning phases, the GMRP successfully implemented and completed a nearly $17,000 \mathrm{~m}^{3}$ monolithic pour of SCC. The quality control and quality assurance programs concluded that the SCC met the design specifications at surface while the installed instrumentation showed that the thermal constraints were met and that the sill pillar did not settle during or after construction.

While the data collected to date shows that during construction the design parameters were met, the in situ integrity of the sill pillar has not been confirmed. Planned future investigations will core through the sill pillar to sample the concrete in several locations. It is intended that this investigation will provide data on the homogeneity of the sill pillar to identify, if present, cold joints or areas of material segregation.

\section{Acknowledgement}

The authors would like to thank Crown-Indigenous Relations and Northern Affairs Canada the owners of the site, Public Services and Procurement Canada, stewards of the site and Nahanni Construction Ltd. the contractor who constructed the sill pillar.

\section{References}

ASTM International 2018, Standard Test Method for Compressive Strength of Cylindrical Concrete Specimens, ASTM C39/C39-18, ASTM International, West Conshohocken.

ASTM International 2016, Standard Test Method for Time of Setting of Concrete Mixtures by Penetration Resistance, ASTM C403/C403M-16, ASTM International, West Conshohocken.

ASTM International 2014a, Standard Test Method for Sieve Analysis of Fine and Coarse Aggregates, ASTM C136/C136M-14, ASTM International, West Conshohocken.

ASTM International 2014b, Standard Test Method for Slump Flow of Self-Consolidating Concrete, ASTM C1611/C1611M-14, ASTM International, West Conshohocken.

ASTM International 1998, Standard Test Method for Expansion and Bleeding of Freshly Mixed Grouts for Preplaced-Aggregate Concrete in the Laboratory, ASTM C940, ASTM International, West Conshohocken.

Crown and Indigenous Relations and Northern Affairs Canada \& Government of the Northwest Territories 2019, Closure and Reclamation Plan for Giant Mine, prepared for the Mackenzie Valley Land and Water Board, Yellowknife.

Google n.d., Giant Mine, https://www.google.com/maps

Preston, R \& Roy, J 2017, 'Use of unmanned aerial vehicles to supplement conventional investigation methods for underground open void stability and mitigation', in Y Potvin \& M Hudyma (eds), Proceedings of the First International Conference on Underground Mining Technology, Australian Centre for Geomechanics, Perth, pp. 609-616.

Rocscience n.d., RS2, computer software, Toronto, https://www.rocscience.com/software/rs2

Silke, $\mathrm{R}$ 2009, The Operational History of Mines in the Northwest Territories, Canada, viewed 8 April 2019, http://www.miningnorth.com/_rsc/site-content/library/NWT_Mines_History_RSilke2009.pdf 